University of Nebraska - Lincoln

DigitalCommons@University of Nebraska - Lincoln

\title{
Grazing Evaluation of Big Bluestems Bred for Improved Forage Yield and Digestibility
}

\author{
R. B. Mitchell \\ USDA-ARS, rob.mitchell@ars.usda.gov \\ Kenneth P. Vogel \\ University of Nebraska-Lincoln, kvogel1@unl.edu \\ T. J. Klopfenstein \\ University of Nebraska-Lincoln, tklopfenstein1@unl.edu \\ B. E. Anderson \\ University of Nebraska-Lincoln \\ R. A. Masters \\ Dow AgroSciences
}

Follow this and additional works at: https://digitalcommons.unl.edu/usdaarsfacpub

Mitchell, R. B.; Vogel, Kenneth P.; Klopfenstein, T. J.; Anderson, B. E.; and Masters, R. A., "Grazing Evaluation of Big Bluestems Bred for Improved Forage Yield and Digestibility" (2005). Publications from USDA-ARS / UNL Faculty. 1923.

https://digitalcommons.unl.edu/usdaarsfacpub/1923

This Article is brought to you for free and open access by the U.S. Department of Agriculture: Agricultural Research Service, Lincoln, Nebraska at DigitalCommons@University of Nebraska - Lincoln. It has been accepted for inclusion in Publications from USDA-ARS / UNL Faculty by an authorized administrator of DigitalCommons@University of Nebraska - Lincoln. 


\title{
Grazing Evaluation of Big Bluestems Bred for Improved Forage Yield and Digestibility
}

\author{
R. B. Mitchell,* K. P. Vogel, T. J. Klopfenstein, B. E. Anderson, and R. A. Masters
}

\section{ABSTRACT}

Two big bluestem (Andropogon gerardii Vitman) strains (Pawnee $\mathrm{C3}$ and Kaw C3) developed by three breeding cycles for increased forage yield and in vitro dry matter digestibility (IVDMD) were compared with the base populations of 'Pawnee' and 'Kaw' in a 3-yr grazing trial. Pastures were seeded in May 1998 near Mead, NE. Experimental units were three 0.4-ha pastures of each strain or cultivar in a randomized complete block design. Pastures were burned and fertilized with ammonium nitrate at $112 \mathrm{~kg} \mathrm{~N} \mathrm{ha}^{-1}$ in the spring of 2000, 2001, and 2002 before grazing. Each pasture was continuously stocked with three crossbred yearling steers (Bos taurus) $(380 \pm 38 \mathbf{~ k g})$ in mid-June 2000, 2001, and 2002 to provide a stock density of 7.5 steers ha ${ }^{-1}$. Pawnee $\mathrm{C} 3$ and Kaw $\mathrm{C3}$ produced 16 and $7 \%$ more average daily gain (ADG), respectively, than the base populations during the 3-yr study. Additionally, Pawnee $\mathrm{C} 3$ and Kaw $\mathrm{C} 3$ produced 14 and $5 \%$ more total body weight $(\mathrm{BW})$ gain $\mathrm{ha}^{-1}$, respectively, than the base populations. Pawnee C3 ADG was $1.30 \mathrm{~kg} \mathrm{hd}^{-1}$ and produced greater than $455 \mathrm{~kg}$ total $\mathrm{BW}$ gain $\mathrm{ha}^{-1}$ during a drought period in eastern Nebraska. Pawnee $\mathrm{C} 3$ pastures produced more available forage with higher IVDMD, cell soluble, cell wall digestibility, and lower lignin concentration than forages from Pawnee pastures. Kaw C3 pastures differed from Kaw pastures by producing forage with greater crude protein concentration. These results demonstrate the productivity of big bluestem pastures in the eastern Great Plains and document the positive livestock response to moderate increases in forage IVDMD. The strains bred for increased yield and IVDMD provided as much as $26 \%$ more total $\mathrm{BW}$ gain $\mathrm{ha}^{-1}$ at no additional cost. Pawnee C3 was released as the cultivar Bonanza and Kaw C3 was released as 'Goldmine'.

$\mathrm{B}$ Ig Bluestem is a $\mathrm{C}_{4}$ perennial grass native to North America (Weaver, 1954) and accounts for over $25 \%$ of the basal cover and over $40 \%$ of the herbaceous biomass of the tallgrass prairie (Weaver and Fitzpatrick, 1934; Masters et al., 1993). The importance of big bluestem in extensively managed native grasslands is recognized by grassland scientists, including Weaver (1954) who called it, "the best prairie grass for both pasture and hay." Big bluestem pastures provide productive, high-quality forage during late spring and summer and may fill the forage availability gap that occurs between

R.B. Mitchell and K.P. Vogel, USDA-ARS, Wheat, Sorghum and Forage Res. Unit, Univ. of Nebraska, PO Box 830937, Lincoln, NE 68583; T.J. Klopfenstein, Dep. of Animal Science, Univ. of Nebraska, Lincoln, NE 68583; B.E. Anderson, Dep. of Agronomy and Horticulture, Univ. of Nebraska, Lincoln, NE 68583; and R.A. Masters, Dow AgroSciences, 8049 Nob Hill Road, Lincoln, NE 68516. This paper is published as Journal Series No. 14873 of the Agric. Res. Div., Univ. of Nebraska. Mention of trade names or commercial products in this publication is solely for the purpose of providing specific information and does not imply recommendation or endorsement by the USDA or the University of Nebraska. Received 9 Dec. 2004. *Corresponding author (rmitchell4@unl.edu).

Published in Crop Sci. 45:2288-2292 (2005).

Forage \& Grazinglands

doi:10.2135/cropsci2004.0716

(c) Crop Science Society of America

677 S. Segoe Rd., Madison, WI 53711 USA the peak spring and autumn production periods for coolseason forages in the eastern Great Plains (Mitchell et al., 1994; Moser and Vogel, 1995). Krueger and Curtis (1979) in South Dakota reported monocultures of Pawnee big bluestem grazed by yearling steers had an average daily gain (ADG) of $0.70 \mathrm{~kg} \mathrm{hd}^{-1}$, and produced $138 \mathrm{~kg}$ total BW gain ha ${ }^{-1}$. They concluded that big bluestem forage can be used successfully for beef production during summer. Conard and Clanton (1963) reported similar results from big bluestem pastures in eastern Nebraska.

Pawnee and Kaw are cultivars of big bluestem that are widely grown for forage in the central Great Plains. Pawnee was originally collected in Pawnee County, NE, and was released jointly by the Nebraska Agricultural Experiment Station (AES) and USDA-ARS in 1963 (Alderson and Sharp, 1994). Kaw is a synthetic variety that originated from several lines collected near Manhattan, KS, and was released in 1950 by the Kansas AES (Alderson and Sharp, 1994). Pawnee is best adapted to USDA Plant Hardiness Zones 4 (lower half) and 5, whereas Kaw is best adapted to Zones 5 (lower half) and 6 (Moser and Vogel, 1995). Kaw is usually 7 to $10 \mathrm{~d}$ later in maturity than Pawnee at the latitude of Mead, $\mathrm{NE}$, which is near the northern limit of its recommended use.

Increasing forage yield and digestibility in perennial grasses may increase livestock performance and profitability of grasslands (Anderson et al., 1988; Hopkins et al., 1993; Vogel and Sleper, 1994; Casler and Vogel, 1999). The objective of this study was to compare beef cattle ADG and total BW gain per hectare on pastures seeded to two big bluestem strains developed by three generations of breeding for increased forage yield and in vitro dry matter digestibility (IVDMD) with the base populations from which the two strains were derived. We hypothesized that the strains bred for increased forage yield and IVDMD (Pawnee C3 and Kaw C3) would produce superior $\mathrm{ADG}$ and total $\mathrm{BW}$ gain per hectare when compared with the parental cultivars. Additional objectives were to determine if the strains differed in stand persistence under grazing, available forage (AF), and nutritive value of AF.

\section{MATERIALS AND METHODS}

Seed of Pawnee C3 and Kaw C3 used to establish the pasture trial was produced in seed increase nurseries at the University of Nebraska Agricultural Research and Development Center (UNL-ARDC) near Mead, NE. Certified seed of Kaw and Pawnee was obtained from commercial vendors. Pastures were seeded in May 1998 at the UNL-ARDC (41.17 N. Lat.,

Abbreviations: ADG, average daily gain; ADL, acid detergent lignin; $\mathrm{AF}$, available forage; $\mathrm{CP}$, crude protein concentration; $\mathrm{CW}$ IVDMD, cell wall digestibility; DM, dry matter content; IVDMD, in vitro dry matter digestibility; NDF, neutral detergent fiber. 
$96.47^{\circ}$ W. Long., Elevation $366 \mathrm{~m}$ ) on a Sharpsburg silty clay loam soil (fine, smectitic, mesic, Typic Argiudoll). Experimental units were three 0.4 -ha pastures of each population, arranged as a randomized complete block design. The pasture area was uniformly cropped in soybean [Glycine $\max$ (L.) Merr.] for $2 \mathrm{yr}$ before pasture seeding. Pastures were seeded no-till into soybean stubble with a Truax drill (Truax Company, Inc., Minneapolis, MN, USA) at a seeding rate of 7.3 to $8.0 \mathrm{~kg} \mathrm{PLS} \mathrm{ha}^{-1}$ (240-260 PLS m ${ }^{-2}$ ). Weed competition during the establishment year was managed with application of the herbicides imazapic (2-[4,5-dihydro-4-methyl-4-(1-methylethyl)-5-oxo- $1 H$-imidazol2-yl]-5-methyl-3-pyridinecarboxylic acid) at $0.07 \mathrm{~kg}^{\mathrm{a} . \mathrm{i}} \mathrm{ha}^{-1}$ and glyphosate [ $N$-(phosphonomethyl)glycine] at $0.70 \mathrm{~kg} \mathrm{ha}^{-1}$ in 1998 before big bluestem seedlings emerged and in the postestablishment year with $1.1 \mathrm{~kg}$ a.i. $\mathrm{ha}^{-1}$ of $2,4-\mathrm{D}$ [(2,4-dichlorophenoxy)acetic acid] low volatile ester and $2.2 \mathrm{~kg}$ a.i. ha ${ }^{-1}$ of atrazine [6-chloro- $N$-ethyl- $N^{\prime}$-(1-methylethyl)-1,3,5-triazine2,4-diamine], and metolachlor [2-chloro- $N$-(2-ethyl-6-methylphenyl)- $N$-(2-methoxy-1-methyl-ethyl)acetamide] following spring burning. Pastures were burned in the spring each year to remove plant residue before grazing. No fertilizer was applied in 1998 or 1999, and no herbicides were applied in 2001. Ammonium nitrate was applied at $112 \mathrm{~kg} \mathrm{~N} \mathrm{ha}^{-1}$ in 2000, 2001, and 2002, and broadleaf weeds were treated with $1.1 \mathrm{~kg}$ a.i. $\mathrm{ha}^{-1}$ of 2,4-D in 2002.

Each pasture was continuously stocked with three crossbred yearling steers $(380 \pm 38 \mathrm{~kg})$ in mid-June 2000, 2001, and 2002 to provide a stock density of 7.5 steers ha ${ }^{-1}$. Initial steer weights were determined by feeding a 50:50 alfalfa-corn (Medicago sativa L.-Zea mays L.) silage diet at $2 \%$ of body weight in a feedlot for $4 \mathrm{~d}$ and weighing at the end of Days 3 and 4 (Moore et al., 1995). The weights for Days 3 and 4 were averaged to determine initial weights. The same feeding and weighing procedure was used after the grazing period to determine final weight to minimize any effects due to fill (Moore et al., 1995). This is a maintenance diet developed for stabilizing animal weights, so the $4 \mathrm{~d}$ of feeding were not included in the yearling performance data. Grazing was initiated on 16 June 2000, 12 June 2001, and 18 June 2002. Steers were allowed to graze the pastures until forage stubble height reached 15 to $20 \mathrm{~cm}$.

Herbage from each pasture was sampled immediately before grazing and at 7-d intervals during grazing to determine AF quantity and quality. Nutritive value assessments included IVDMD, crude protein concentration (CP), neutral detergent fiber (NDF), acid detergent lignin (ADL), and cell wall digestibility (CW IVDMD). Available forage was determined by hand-clipping all herbage to a $10-\mathrm{cm}$ stubble height within three, $0.54-\mathrm{m}^{2}$ rectangular quadrats randomly-located within each pasture.

Harvested samples were dried in a forced-air oven at $50^{\circ} \mathrm{C}$ to a constant weight and dry weight determined. Dried samples were ground to pass a 2-mm screen in a Wiley mill and a 1-mm screen in a cyclone mill (Thomas-Wiley Mill Co., Philadelphia, PA) and scanned on a near-infrared reflectance spectrophotometer (NIRS; Model 6500, Silver Spring, MD). A calibration set of 212 samples for IVDMD, NDF, and ADL, and 244 samples for CP was chosen by cluster analysis of the reflectance data (Shenk and Westerhaus, 1991). Calibration samples were analyzed in triplicate for IVDMD with the ANKOM Rumen Fermenter (ANKOM Technology Corp., Fairport, NY) by the procedures described by Vogel et al. (1999). Crude protein concentration $(\% \mathrm{~N} \times 6.25)$ was determined by the LECO combustion method (Model FP 428 and FP 2000, LECO Corp., St. Joseph, MI) (Watson and Isaac, 1990; Bremner, 1996). Calibration samples were analyzed in duplicate for NDF and ADL with the ANKOM Fiber Analyzer (ANKOM Technology Corp., Fairport, NY) by the procedures described by Vogel et al. (1999) and the ANKOM ADL procedure (ANKOM Technology-9/99, Method for Determining Acid Detergent Lignin in Beakers). Laboratory means were used to develop calibration equations by partial least squares (Shenk and Westerhaus, 1991). Values of IVDMD, CP, NDF, and ADL were predicted for each year with a single calibration equation per variable. Calibration statistics for IVDMD in 2000, 2001, and 2002, respectively, were: $\mathrm{SEP}=1.55,2.05$, and $3.28 \mathrm{~g} \mathrm{~kg}^{-1} ; R^{2}=0.95,0.88$, and 0.84 . Calibration statistics for $\mathrm{CP}$ in 2000, 2001, and 2002, respectively, were: SEP = $0.10,0.09$, and $0.09 \mathrm{~g} \mathrm{~kg}^{-1} ; R^{2}=0.94,0.94$, and 0.96. Calibration statistics for NDF in 2000, 2001, and 2002, respectively, were: SEP $=0.70,0.59$, and $1.61 \mathrm{~g} \mathrm{~kg}^{-1} ; R^{2}=0.92,0.91$, and 0.69 . Calibration statistics for ADL in 2000, 2001, and 2002 were $\mathrm{SEP}=0.37,0.37$, and $0.47 \mathrm{~g} \mathrm{~kg}^{-1} ; R^{2}=0.90,0.83$, and 0.72 . Cell wall digestibility (CW IVDMD) was calculated as CW

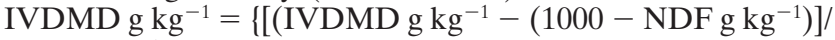
$\left.\mathrm{NDF} \mathrm{g} \mathrm{kg}^{-1}\right\} \times 1000$, with the assumption that cell constituents are completely digested.

Big bluestem stand persistence was determined in June 2000 and September 2002 by the frequency grid that followed procedures described by Vogel and Masters (2001). Big bluestem frequency of occurrence was measured in 2000, and big bluestem and weed frequency of occurrence were measured in 2002 at three randomly selected locations in each pasture. Analysis of variance (ANOVA) procedures were used to test for differences among strains for $\mathrm{ADG}$, total $\mathrm{BW}$ gain ha ${ }^{-1}$, AF, IVDMD, CP, NDF, ADL, CW IVDMD, and stand persistence. Statistical significance is at the 0.05 probability level unless otherwise stated. Pasture was the experimental unit for all analyses.

\section{RESULTS}

Differences in precipitation distribution (Fig. 1) provided 62 grazing days in 2000, 43 grazing days in 2001, and 38 grazing days in 2002. August precipitation in 2001 and 2002 provided additional late summer grazing $\left(\sim 8 \mathrm{AUM} \mathrm{ha}^{-1}\right)$ that was not included in the livestock performance data.

\section{Pasture Persistence}

The pastures were well established and there were no significant differences among the big bluestem strains for grass frequency of occurrence at grazing trial initiation. Grass frequency of occurrence for all pastures averaged $89 \%$ before grazing in June of 2000 . When the trial ended in September of 2002 after the third grazing season, grass frequency of occurrence averaged $77 \%$ and Kaw C3 $(71 \%)$ was different $(P=0.04)$ than Pawnee and Kaw. In the Central Great Plains with native warmseason grasses, grass frequency of occurrence greater than $50 \%$ were similar to plant density of native prairie and are considered to be fully satisfactory (Vogel and Masters, 2001). Initial stands of native grasses often decrease as stands mature and individual plants become larger as occurred in this trial. Weed pressure as determined by the frequency grid was low, ranging from 1.1 to $5.8 \%$ at the end of the trial with no significant differences among strains.

\section{Livestock Performance}

There were significant differences among strains for $\mathrm{ADG}$ and $\mathrm{BW}$ gain per hectare (Table 1). Livestock 


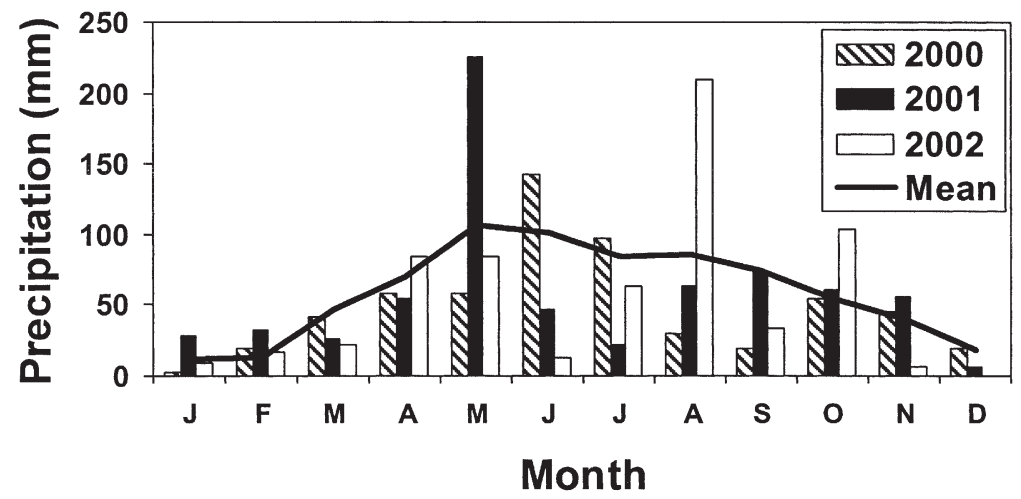

Fig. 1. Monthly precipitation received at Mead, NE, in 2000, 2001, and 2002 (NOAA, 2003). Monthly mean precipitation is represented by the solid line. Total annual precipitation was 587, 695, and $646 \mathrm{~mm}$ in 2000, 2001, and 2002, respectively, with a long-term average of $704 \mathrm{~mm}$.

gains were consistent over years and pastures with an exception that cattle grazing one Kaw pasture in 2000 had an ADG of $1.52 \mathrm{~kg} \mathrm{hd}^{-1}$, which was $19 \%$ greater than any other pasture that year. This was due to a single animal gaining almost $0.45 \mathrm{~kg} \mathrm{~d}^{-1}$ more than any of the other 35 animals in the trial that year. The reason for the high ADG of a single steer is not known, but the data were included in the analysis. Year $\times$ strain interactions for $\mathrm{ADG}$ and $\mathrm{BW}$ gain per hectare were not significant indicating that performance over years was relatively consistent across strains. Total BW gain per hectare differed $(P<0.0001)$ across years (Table 1$)$, with the difference among years being largely due to differences in precipitation (Fig. 1) that affected forage production and grazing days. Body weight gain per hectare was greatest in 2000 when rains in late May and early June promoted the growth of more than $5 \mathrm{Mg}$ $\mathrm{ha}^{-1}$ of $\mathrm{AF}$ at grazing initiation, nearly twice as much as in 2001 and 2002. Because strain $\times$ year effects were not significant, mean performances on strains averaged over years will be discussed.

Averaged over the $3 \mathrm{yr}$, Pawnee C3 and Kaw C3 produced $16 \%(P \leq 0.05)$ and $7 \%(P \leq 0.20)$ greater ADG, respectively, than their parent populations (Table 1). Pawnee C3 produced higher ADG than its parent population, Pawnee, each year of the grazing trial. In 2002, ADG for Kaw C3 was 23\% greater than Kaw pastures. Total BW gain per hectare also differed significantly among strains. Pawnee C3 pastures produced $14 \%$ more gain ha ${ }^{-1}(P \leq 0.05)$ than Pawnee pastures. Kaw C3 pastures produced 5\% more gain per hectare than Kaw pastures. Mean total BW gain per hectare per year for the $3 \mathrm{yr}$ of the study ranged from $398 \mathrm{~kg}$ for Pawnee to $455 \mathrm{~kg}$ for Pawnee C3.

\section{Forage Availability and Nutritive Value}

There were significant differences among strains for AF and average grazing season forage IVDMD, NDF, ADL, CP, and CW IVDMD (Table 2). Because of precipitation differences, there were significant year effects for all forage traits, but strain $\times$ year effects were not significant for any forage trait except for ADL (data not shown). For ADL, strain effects were more than two times greater than strain $\times$ year effects in the $\mathrm{AN}$ OVA. The nonsignificant strain $\times$ year effects demonstrate that AF and nutritive value of the strains ranked in a similar manner each year even with the differences in available precipitation.

Pawnee C3 pastures had 14\% greater AF than the Pawnee pastures over the three grazing seasons and the AF from the Pawnee C3 pastures had greater IVDMD, lower NDF, lower ADL, and greater CW IVDMD concentrations than forage from the Pawnee pastures (Table 2). Since NDF is an estimate of total cell walls, Pawnee C3 forage had a lower concentration of cell walls and had more digestible cell walls than Pawnee forage. Pawnee C3 cell walls were likely more digestible because of their lower lignin concentration. Pawnee C3 pastures produced more ADG and total BW gain per hectare than Pawnee pastures because of both greater AF and forage digestibility.

Kaw C3 and Kaw pastures did not differ in AF or forage IVDMD, NDF, and CW IVDMD (Table 2). Forage from the Kaw $\mathrm{C} 3$ pastures had higher $\mathrm{CP}$ but also had higher ADL. The small differences in quality between Kaw C3 and Kaw resulted in smaller differences in ADG by cattle grazing these pastures than for those grazing Pawnee C3 and Pawnee. Since animals graze

Table 1. Beef cattle gains on fertilized big bluestem pastures at Mead, NE in 2000, 2001, and 2002.

\begin{tabular}{|c|c|c|c|c|c|c|c|c|c|}
\hline \multirow[b]{2}{*}{ Strain } & \multicolumn{4}{|c|}{ Average daily gain } & \multicolumn{4}{|c|}{ Total body weight gain } & \multirow{2}{*}{$\begin{array}{l}\text { Mean net } \\
\text { return }\end{array}$} \\
\hline & 2000 & 2001 & 2002 & Mean & 2000 & 2001 & 2002 & Mean & \\
\hline & \multicolumn{4}{|c|}{$-\mathbf{k g ~ h d ^ { - 1 }}$} & \multicolumn{4}{|c|}{ kg ha ${ }^{-1}$} & $\$ h^{-1} \mathbf{y r}^{-1} \uparrow$ \\
\hline Pawnee & 1.19 & 1.02 & 1.14 & 1.12 & 549 & 324 & 322 & 398 & 263 \\
\hline Pawnee C3 & 1.25 & 1.28 & 1.36 & 1.30 & 572 & 409 & 383 & 455 & 300 \\
\hline Kaw & 1.27 & 1.19 & 1.11 & 1.19 & 581 & 380 & 311 & 424 & 278 \\
\hline Kaw C3 & 1.18 & 1.27 & 1.37 & 1.27 & 542 & 404 & 385 & 444 & 293 \\
\hline Mean & 1.22 & 1.19 & 1.25 & 1.22 & 561 & 379 & 350 & 430 & 284 \\
\hline SE & 0.03 & 0.05 & 0.05 & 0.04 & 16 & 16 & 15 & 13 & \\
\hline
\end{tabular}

$\uparrow$ Net return $\left(\$ \mathrm{ha}^{-1} \mathrm{yr}^{-1}\right)$ is calculated as mean body weight gain ha $\mathbf{h}^{-1} \times \$ 0.66 \mathbf{k g}^{-1}$ gain (Mitchell et al., 2005$)$. 
Table 2. Available forage (AF), in vitro dry matter digestibility (IVDMD), crude protein concentration (CP), NDF, cell wall (CW) IVDMD, and acid detergent lignin (ADL) of available forage from four big bluestem populations grazed by beef cattle near Mead, NE. Values represent the mean of samples collected at 7-d intervals while the pastures were being grazed in 2000 , 2001, and 2002.

\begin{tabular}{|c|c|c|c|c|c|c|}
\hline Strain & $\mathbf{A F}$ & IVDMD & $\mathbf{C P}$ & NDF & CW IVDMD & ADL \\
\hline & $\mathrm{Mg} \mathrm{ha}^{-1}$ & & & $-\mathbf{g ~ k}$ & & \\
\hline Pawn & 2.79 & 593 & 95 & 718 & 435 & 57 \\
\hline Pa & 3. & 608 & 94 & 713 & & 56 \\
\hline Kaw & 2.92 & 612 & 94 & 711 & 455 & 56 \\
\hline Kaw C3 & 2.77 & 612 & 97 & 711 & 456 & 57 \\
\hline $\mathbf{S E}$ & 0.12 & 1.8 & 0.9 & 1.3 & 2.1 & 0.3 \\
\hline
\end{tabular}

daily, they sample pastures more thoroughly and intensively than weekly or even daily hand collection (Vogel and Sleper, 1994).

Kaw and Kaw C3 are near the northern limits of their range of adaptation at the latitude of this grazing trial. Kaw and Kaw C3 are later in maturity than Pawnee and Pawnee $\mathrm{C} 3$ and because of the strong negative correlation between IVDMD and maturity in big bluestem (Mitchell et al., 2001), they are usually higher in IVDMD on a given date simply because of maturity effects. Direct comparisons between Pawnee and Pawnee C3 vs. Kaw and Kaw C3 are strongly biased by maturity effects for both forage quality and yield. The main comparisons in this study are between Pawnee and Pawnee C3 and Kaw and Kaw C3. In both cases, the big bluestem strain bred for improved forage yield and IVDMD produced higher ADG and gains per hectare as compared with its parent population when grazed by beef cattle.

\section{DISCUSSION}

Livestock performance information on big bluestem monocultures is limited. Conard and Clanton (1963) reported a mean ADG of $0.56 \mathrm{~kg} \mathrm{hd}^{-1}$ during a 3-yr grazing study on big bluestem monocultures in Nebraska. A 3-yr grazing study in South Dakota reported a mean ADG of $0.70 \mathrm{~kg} \mathrm{hd}^{-1}$ on monocultures of Pawnee big bluestem (Krueger and Curtis, 1979). Both studies reported significantly less ADG than the 1.22 $\mathrm{kg} \mathrm{hd}^{-1}$ observed across all strains and years in this study. The pastures in previous studies (Conard and Clanton, 1963; Krueger and Curtis, 1979) were not managed for high levels of livestock gains. The pastures in those studies were not fertilized and were stocked at lower densities that likely allowed ungrazed forage to mature and decrease in quality and probably reduced their ADG in comparison with this study. The higher beef cattle gain per ha achieved grazing big bluestem pastures in this study was likely due to improvements in both management and the plant materials grown in the pastures.

Casler and Vogel (1999) presented a model for predicting the change in ADG on the basis of the change in IVDMD [ $\%$ change in ADG $=5.0+3.24$ ( $\%$ change in IVDMD)] that predicted a $2.9 \%$ increase in IVDMD should result in a $14.4 \%$ increase in ADG, which closely approximates the $16 \%$ increase we observed in Pawnee C3. However, their model for predicting the change in animal production per hectare [\% change in animal production $=13.8+2.75(\%$ change in IVDMD $)]$ was not as robust and predicted a $2.9 \%$ increase in IVDMD should result in a $21.8 \%$ increase in animal production per ha, which overestimated the $14 \%$ increase we observed in Pawnee C3. However, Casler and Vogel (1999) made no corrections for decreased forage availability because of environmental stresses, such as drought conditions that occurred during this study.

These results support our hypothesis that big bluestems bred for increased forage yield and IVDMD would produce greater ADG and beef production per hectare when compared with their parental cultivars. The results of this 3-yr grazing trial further demonstrate the productivity of big bluestem pastures in the eastern Great Plains and document the positive livestock response to moderate increases in forage IVDMD. The strains bred for increased yield and IVDMD provided as much as $26 \%$ more BW gain per hectare at no additional cost. Using net returns per kilogram of gain for the 3-yr of this trial (Mitchell et al., 2005), producers could realize from $\$ 13$ to $\$ 90$ more net return per hectare by planting improved strains rather than currently available cultivars (Table 1).

Pawnee C3 and Kaw C3 were released as the cultivars Bonanza and Goldmine, respectively. Bonanza is suggested for use in USDA Plant Hardiness Zones lower 4 and 5, whereas Goldmine is suggested for use in USDA Plant Hardiness Zones lower 5 and 6 east of $100^{\circ} \mathrm{W}$. Long. These releases represent the first big bluestem cultivars developed specifically for increased animal performance by increasing forage yield and IVDMD and validated by grazing trials.

\section{REFERENCES}

Alderson, J., and W.C. Sharp. 1994. Grass varieties in the United States. USDA Handb. 170 (Revised). U.S. Gov. Print. Office, Washington, DC.

Anderson, B.E., J.K. Ward, K.P. Vogel, M.G. Ward, H.J. Gorz, and F.A. Haskins. 1988. Forage quality and performance of yearlings grazing switchgrass strains selected for differing digestibility. J. Anim. Sci. 66:2239-2244.

Bremner, J.M. 1996. Nitrogen-Total. p. 1085-1121. In D.L. Sparks et al. (ed.) Methods of soil analysis. Part 3. Chemical methods. SSSA Book Ser. 5. SSSA and ASA, Madison, WI.

Casler, M.D., and K.P. Vogel. 1999. Accomplishments and impact from breeding for increased forage nutritional value. Crop Sci. 39: $12-20$.

Conard, E.C., and D.C. Clanton. 1963. Cool-season, warm-season pastures needed. Nebraska Agric. Exp. Stn. Beef Cattle Progress Report. Univ. of Nebraska. 1963:11-13.

Hopkins, A.A., K.P. Vogel, and K.J. Moore. 1993. Predicted and realized gains from selection for in vitro dry matter digestibility and forage yield in switchgrass. Crop Sci. 33:253-258.

Krueger, C.R., and D.C. Curtis. 1979. Evaluation of big bluestem, indiangrass, sideoats grama, and switchgrass pastures with yearling steers. Agron. J. 71:480-482.

Masters, R.A., R.B. Mitchell, K.P. Vogel, and S.S. Waller. 1993. Influence of improvement practices on big bluestem and indiangrass seed production in tallgrass prairies. J. Range Manage. 46:183-188.

Mitchell, R., J. Fritz, K. Moore, L. Moser, K. Vogel, D. Redfearn, and D. Wester. 2001. Predicting forage quality in switchgrass and big bluestem. Agron. J. 93:118-124.

Mitchell, R.B., R.A. Masters, S.S. Waller, K.J. Moore, and L.E. Moser. 1994. Big bluestem production and forage quality responses to 
burning date and fertilizer in tallgrass prairies. J. Prod. Agric. 7: 355-359.

Mitchell, R., K. Vogel, G. Varvel, T. Klopfenstein, D. Clark, and B. Anderson. 2005. Big bluestem pasture in the Great Plains: An alternative for dryland corn. Rangelands 27(2):31-35.

Moore, K.J., K.P. Vogel, T.J. Klopfenstein, R.A. Masters, and B.E. Anderson. 1995. Evaluation of four intermediate wheatgrass populations under grazing. Agron. J. 87:744-747.

Moser, L.E., and K.P. Vogel. 1995. Switchgrass, big bluestem, and indiangrass. p. 409-420. In R.F Barnes et al. (ed.) Forages: An introduction to grassland agriculture. 5th ed. Iowa State Univ. Press, Ames.

NOAA. 2003. Annual weather data for Nebraska, National Climatic Data Center, Asheville, NC. (www5.ncdc.noaa.gov/pdfs/cd/nebraska/, verified 30 September 2004).

Shenk, J.S., and M.O. Westerhaus. 1991. Population definition, sample selection, and calibration procedures for near infrared reflectance spectroscopy. Crop Sci. 31:469-474.

Vogel, K.P., and R.A. Masters. 2001. Frequency grid-A simple tool for measuring grassland establishment. J. Range Manage. 54:653-655.

Vogel, K.P., J.F. Pedersen, S.D. Masterson, and J.J. Toy. 1999. Evaluation of a filter bag system for NDF, ADF, and IVDMD forage analysis. Crop Sci. 39:276-279.

Vogel, K.P., and D.A. Sleper. 1994. Alteration of plants via genetics and plant breeding. p. 891-921. In G.C. Fahey, Jr. (ed.) Forage quality, evaluation, and utilization. ASA, CSSA, SSSA. Madison, WI.

Watson, M.E., and R.A. Isaac. 1990. Analytical instruments for soil and plant analysis. p. 691-704. In R.L. Westerman (ed.) Soil testing and plant analysis. 3rd ed. SSSA Book Ser. 3. SSSA, Madison, WI.

Weaver, J.E. 1954. North American Prairie. Johnsen Publ. Co., Lincoln, NE.

Weaver, J.E., and T.J. Fitzpatrick. 1934. The Prairie. Ecol. Monogr. 4:109-295. 